\title{
Synthesis and Biological Study of Some New Pyrrolidines
}

\author{
A.J. Al-Hamdany \\ Chemistry Dept., Science Coll. \\ Mosul Univ., Mosul-Iraq
}
A.M. Mustapha
Chemistry Dept.
M.S. Abdul-Rahman
Biology Dept. Education Coll., Duhok Univ., Duhok-Iraq

Received

3/7/2006
Accepted

9/1/2007

\begin{abstract}
الخلاصة
تم تحضير سلسلة من قواعد شيف N-ارايليدين بنزايل امين (1-6) من خلال الاضافة الحلقية الانيونية نوع 1،3 وتحت ظروف قاعدية قوية تمت اضافتها على البنزوكوينون لتتتج البايروليدينات الجديدة الملتحمة (7-12). نم استعمال الطرق الطيفية لاثبات تراكيب النواتج فئن الجديدة. ان الميكانيكيات المقترحة لاكثر التفاعلات تم التحقق منها نظريا اعتمادا على قيم حرارة

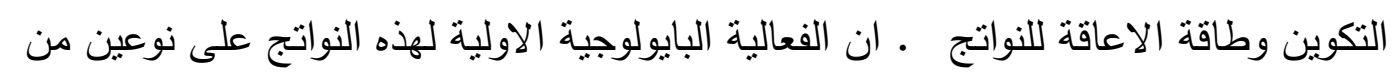

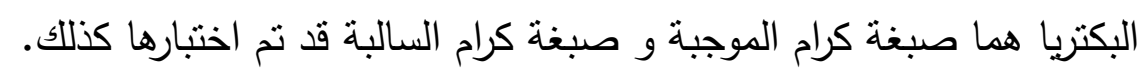

\begin{abstract}
A series of Schiff bases N-Arylidene benzylamie (1-6) have been prepared, and through 1,3-anionic cycloaddition under strong basic conditions were added to benzoquinone to afford the fused new pyrrolidines (7-12). The spectroscopic methods were used to confirm the structures of the new products, as well as melting points. The suggested mechanisms of most of the reactions were investigated theoretically on the basis of the values of heat of formation and steric energy of the products. A preliminary biological activity on E. coli and Staph. aureus of the products had also been tested.
\end{abstract}




\section{INTRODUCTION}

Pyrrolidines are a series of important compounds which reflect an intriguing structures and potent biological activity, which concentrates about among their ability to inhibit a variety of glycosidases ${ }^{(1)}$. Many experiments were performed using (s)-1-(2-pyrrolidinyl methyl) pyrrolidine as catalyst in catalytic direct asymmetric Michael reactions ${ }^{(2)}$. It was found that (s)-2-(morpholinomethyl) pyrrolidine (I) was the most effective catalyst in terms of stereochemical control. Providing a high level of diastereoselection and good enantioselection ${ }^{(3)}$.

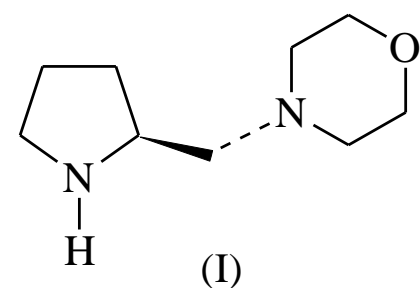

Cycloadditions are of a clear significance, when considering methods to ring-containing structures, since they have the advantages of synthetic efficiency and potentially high stereoselectivity. Among the possible cycloadditions strategies that might be used to make a pyrrolidine ring. So it was chosen to display disconnection of the $\mathrm{C} 2 / \mathrm{C} 3$ and $\mathrm{C} 4 / \mathrm{C} 5$ bonds, thus need to use either azaallyl anion (II) or an azomethine yield (III) in a ( $\square 4 \mathrm{~s}+\square 2 \mathrm{~s}$ ) cycloaddition with an alkene ${ }^{(4)}$.

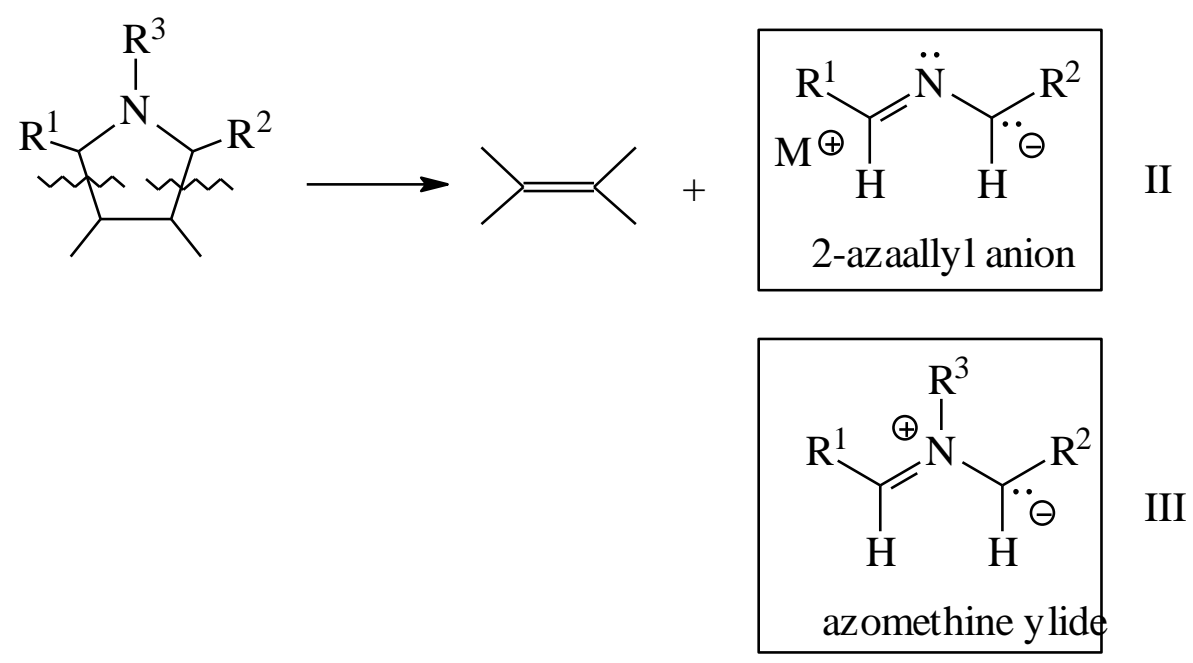

Scheme (1): (3+2) Approaches to the pyrrolidine 


\section{A.J. Al-Hamdany, A.M. Mustapha\& M.S. Abdul-Rahman}

It is worth mentioning that there are many compounds known as a natural and others are synthetic and both are biologically active ${ }^{(5)}$, in addition to chiral auxiliaries and ligands ${ }^{(6)}$ containing a pyrrolidine moiety, and consequently new methods providing access to enantiopure derivatives of this heterocycle are of current interest, that is to say that the synthesis of pyrrolidine ring is of a great importance, due to its biological interest.

\section{Instrumentation:}

\section{EXPERIMENTAL}

1. Melting points were determined by Electrothermal 9000 Digital-Series 1998 Apparatus (uncorrected).

2. Boiling points were determent by inverted capillary in a Thiele tube using paraffin colourless ${ }^{(7)}$ oil.

3. Ultraviolet spectra were obtained using SPECORD 200 UV-Visible double beam Analytikjena Spectraphotometer.

4. Fourier-Transform Infrared (FT-IR) spectra were recorded using Thermo-Nicolte Fourier-Transform Infrared (FT-IR) Spectrophotometer.

5. The data obtained from the minimized geometry were used for the theoretical calculations. The theoretical calculations were computed using semi-empirical $\mathrm{AM}_{1}$ module in the CS ChemOffice molecular modeling package. 


\section{Synthesis:}

\section{Preparation of Schiff bases (1-6):}

\section{General procedure ${ }^{(8)}$ :}

Benzylamine $(1.1 \mathrm{ml}, 0.01$ mole) was heated with (0.01) mole of substituted benzaldehyde in(10)ml n-butanol for (10) min. in a $100 \mathrm{ml}$ beaker at $(100){ }^{\circ} \mathrm{C}$. The reaction mixture then cooled and the product being purified (the solid products were recrestallized from ethanol whereas the liquid products were distilled for purification). The structure, names, some physical properties and spectral data were illustrated in Table (1). The spectra data were in a good agreement with the reported values $^{(9,10)}$.

\section{Preparation of fused heterocycles (7-12):}

General procedure $^{(11)}$ :

A mixture of (10) mmole Schiff base and (0.55 gm, 5 mmole) mmole of benzoquinone was stirred in the presence of (3) $\mathrm{ml}$ of $50 \%$ alcoholic sodium hydroxide solution. and dimethyl sulfoxide (10) $\mathrm{ml}$ stirring continued for (2) hrs at room temperature, then the mixture allowed to stand overnight. A (100) $\mathrm{ml}$ of water was added, the separated precipitates were filtered, washed with water till the filtrate being clear and neutral. The solid products were dried and recrystallised from methanol-ethyl acetate. Table (2) illustrates physical properties and spectral data of products.

Table (1): Structures, names, physical and spectral data of Schiff bases

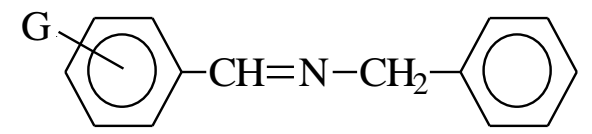

\begin{tabular}{|c|c|c|c|c|c|c|c|}
\hline \multirow{2}{*}{$\begin{array}{l}\text { Comp. } \\
\text { No. }\end{array}$} & \multirow[t]{2}{*}{$\mathrm{G}$} & \multirow[t]{2}{*}{ Name } & \multirow{2}{*}{$\begin{array}{l}\text { m.p. } \\
\left({ }^{\circ} \mathrm{C}\right)\end{array}$} & \multirow{2}{*}{$\begin{array}{l}\text { Yield } \\
(\%)\end{array}$} & \multirow{2}{*}{$\begin{array}{l}\mathrm{UV}\left(\mathrm{CHCl}_{3}\right) \\
\square_{\max }(\mathrm{nm})\end{array}$} & \multicolumn{2}{|c|}{$\begin{array}{l}\text { IR }(\mathrm{KBr}) \\
\square\left(\mathrm{cm}^{-1}\right)\end{array}$} \\
\hline & & & & & & $\mathrm{C}=\mathrm{N}$ & Others \\
\hline 1 & $\mathrm{H}$ & $\begin{array}{l}\text { N-Benzylidene } \\
\text { benzylamine }\end{array}$ & $\begin{array}{c}275-276 \\
\text { Liquid }\end{array}$ & 70 & 292 & 1660 & (1) \\
\hline 2 & $\mathrm{o}-\mathrm{Cl}$ & $\begin{array}{c}\mathrm{N} \text {-(o-Chlorobenzylidene) } \\
\text { benzylamine }\end{array}$ & $139-140$ & 40 & 290 & 1665 & $\begin{array}{l}750 \\
\mathrm{C}-\mathrm{Cl}\end{array}$ \\
\hline 3 & $\mathrm{p}-\mathrm{Br}$ & $\begin{array}{c}\mathrm{N} \text {-(p-Bromobenzylidene) } \\
\text { benzylamine }\end{array}$ & $39-41$ & 85 & 336 & 1668 & $\begin{array}{c}700 \\
\mathrm{C}-\mathrm{Br}\end{array}$ \\
\hline 4 & $\mathrm{p}-\mathrm{NO}_{2}$ & $\begin{array}{l}\mathrm{N} \text {-(p-Nitrobenzylidene) } \\
\text { benzylamine }\end{array}$ & $50-52$ & 60 & 338 & 1675 & $\begin{array}{c}1500 \text { asym. } \\
1340 \text { sym. } \\
\mathrm{N} \cdots \mathrm{O}\end{array}$ \\
\hline 5 & $\mathrm{p}-\mathrm{OCH}_{3}$ & $\begin{array}{c}\mathrm{N} \text {-(p-Methoxybenzylidene) } \\
\text { benzylamine }\end{array}$ & $202-204$ & 75 & 290 & 1650 & $\begin{array}{c}1145 \\
\mathrm{C}-\mathrm{O}-\mathrm{C}\end{array}$ \\
\hline 6 & 2,4-di-OCH 3 & $\begin{array}{c}\mathrm{N}-(2,4- \\
\begin{array}{c}\text { Dimethoxybenzylidene }) \\
\text { benzylamine }\end{array}\end{array}$ & $\begin{array}{c}125-126 \\
\text { Liquid }\end{array}$ & 60 & 339 & 1645 & $\begin{array}{c}1140 \\
\mathrm{C}-\mathrm{O}-\mathrm{C}\end{array}$ \\
\hline
\end{tabular}


Table (2): Physical and spectral data of products (7-12)

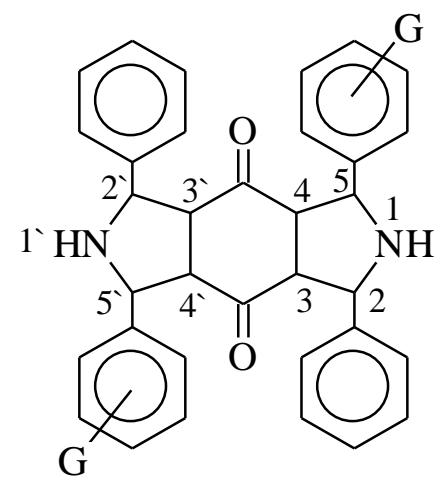

\begin{tabular}{|c|c|c|c|c|c|c|c|c|}
\hline \multirow{2}{*}{$\begin{array}{c}\text { Comp. } \\
\text { No. }\end{array}$} & \multirow[t]{2}{*}{$\mathrm{G}$} & \multirow[t]{2}{*}{ Name } & \multirow{2}{*}{$\begin{array}{l}\text { m.p. } \\
\left({ }^{\circ} \mathrm{C}\right)\end{array}$} & \multirow{2}{*}{$\begin{array}{c}\text { Yield } \\
(\%)\end{array}$} & \multirow{2}{*}{$\begin{array}{l}\mathrm{UV}\left(\mathrm{CHCl}_{3}\right) \\
\square \text { max }(\mathrm{nm})\end{array}$} & \multicolumn{3}{|c|}{$\begin{array}{c}\text { IR }(\mathrm{KBr}) \\
\square\left(\mathrm{cm}^{-1}\right)\end{array}$} \\
\hline & & & & & & $\mathrm{C}=\mathrm{O}$ & $\mathrm{N}-\mathrm{H}$ & $\mathrm{NH}_{2}{ }^{+}$ \\
\hline 7 & $\mathrm{H}$ & $\begin{array}{c}\text { Bis-[2,5-diphenyl pyrrolidino]- } \\
\text { [4,3-b:4 ,3-e]-1,4- } \\
\text { cyclohexadione }\end{array}$ & 144-146 & 58 & 346 & 1637 & 3062 & 2360 \\
\hline 8 & $\mathrm{o}-\mathrm{Cl}$ & $\begin{array}{c}\text { Bis-[2-phenyl-5-(o- } \\
\text { chlorophenyl) pyrrolidino]-[4,3- } \\
\text { b:4`,3'-e]-1,4-cyclohexadione }\end{array}$ & & 30 & 340 & 1628 & 3385 & 2361 \\
\hline 9 & $\mathrm{p}-\mathrm{Br}$ & $\begin{array}{c}\text { Bis-[2-phenyl-5-(p- } \\
\text { bromophenyl) pyrrolidino]- } \\
{[4,3-\mathrm{b}: 4,3-\mathrm{e}]-1,4-} \\
\text { cyclohexadione }\end{array}$ & $82-84$ & 50 & 294 & 1698 & 3060 & 2360 \\
\hline 10 & $\mathrm{p}-\mathrm{NO}_{2}$ & $\begin{array}{l}\text { Bis-[2-phenyl-5-(p-nitrophenyl) } \\
\text { pyrrolidino]-[4,3-b:4',3'-e]-1,4- } \\
\text { cyclohexadione }\end{array}$ & $190-192$ & 45 & 303 & $\begin{array}{r}1633 \\
\mathrm{~N} \cdots \mathrm{O} \\
1527\end{array}$ & 3383 & 2360 \\
\hline 11 & $\mathrm{p}-\mathrm{OCH}_{3}$ & $\begin{array}{c}\text { Bis-[2-phenyl-5-(p- } \\
\text { methoxyphenyl) pyrrolidino]- } \\
{\left[4,3-\mathrm{b}: 4^{`}, 3^{`}-\mathrm{e}\right]-1,4-} \\
\text { cyclohexadione } \\
\end{array}$ & $142-144$ & 35 & 291 & 1633 & 3235 & 2360 \\
\hline 12 & 2,4-di- $\mathrm{OCH}_{3}$ & $\begin{array}{c}\text { Bis-[2-phenyl-5-(2`,4- } \\
\text { dimethoxyphenyl) pyrrolidino]- } \\
{\left[4,3-\mathrm{b}: 4^{`}, 3^{`} \text {-e]-1,4- }\right.} \\
\text { cyclohexadione }\end{array}$ & $158-160$ & 45 & 297 & 1670 & 3421 & 2360 \\
\hline
\end{tabular}

\section{RESULTS AND DISCUSSION}

The condensation of substituted benzaldehydes with benzylamine in n-butanol leads to the corresponding imines ${ }^{(9,10)}$ (Schiff base 1-6 which had been confirmed depending on spectral data).

The UV spectra showed a range of (290-339) nm which agree with the literature values ${ }^{(12)}$ for such compounds. On the other hand the IR spectra manifested a range of stretching vibrations of $(1675-1645) \mathrm{cm}^{-1}$ related $^{(13)}$ to the carbon-nitrogen double bond $(\square \mathrm{C}=\mathrm{N})$. Table (1) illustrates the spectral data of the prepared Schiff bases in addition to structures, names and melting points. 
The suggested mechanism ${ }^{(14)}$ of this cycloaddition may pass through the following route (Scheme 1): The strong alkaline medium abstracts the acidic hydrogen from $-\mathrm{CH}_{2}$ - in the Schiff base to produce the anion An1 which may resonate to give the anion An2. The equivalent hybrid of An1 and An2 is An3 (Scheme 2).
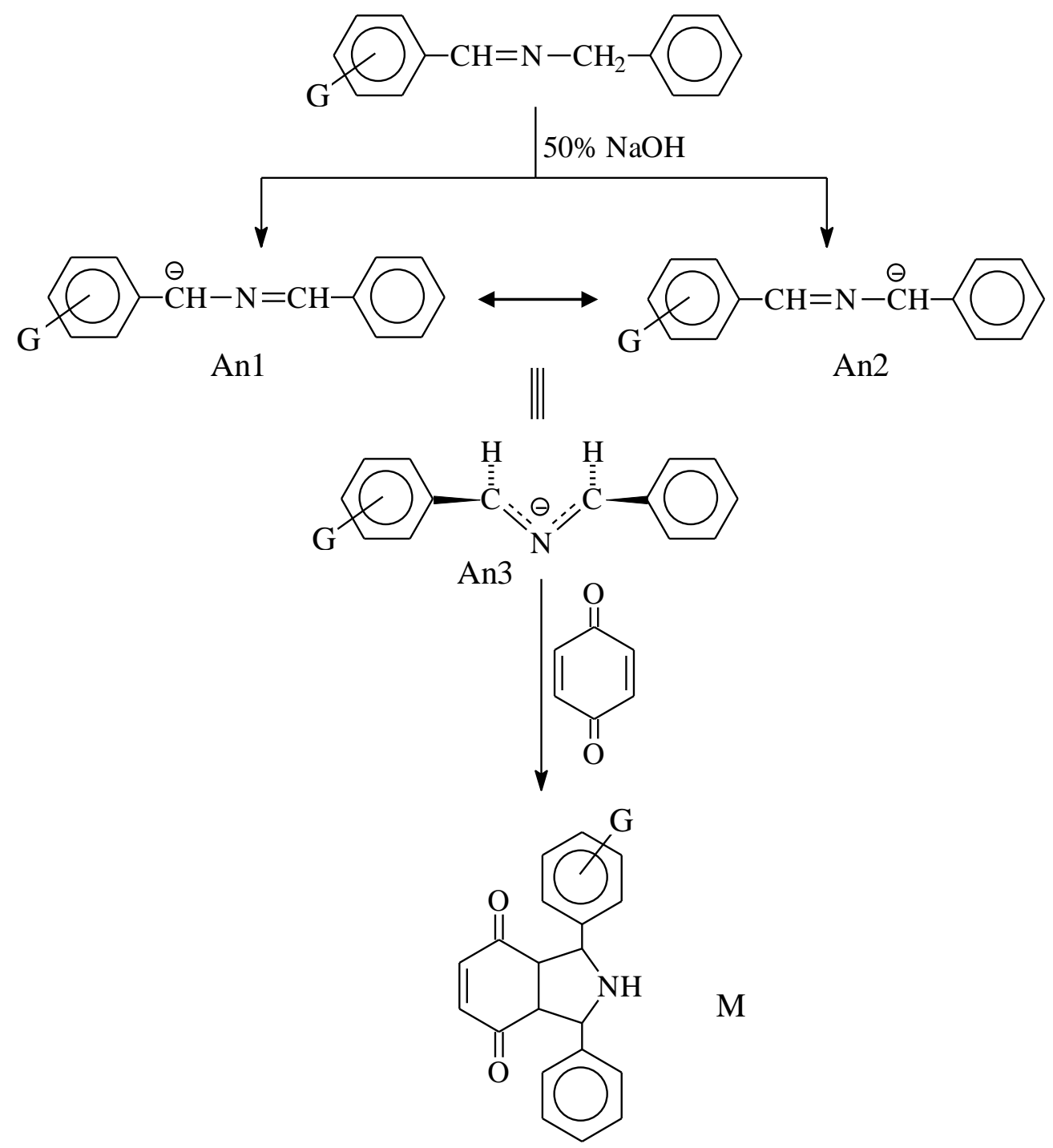

\begin{tabular}{cll} 
Comp. No & & G \\
\hline 7 & & H \\
8 & & o-Cl \\
9 & & p-Br \\
10 & & p-NO \\
11 & & p-MeO \\
12 & & $2,4-$
\end{tabular}

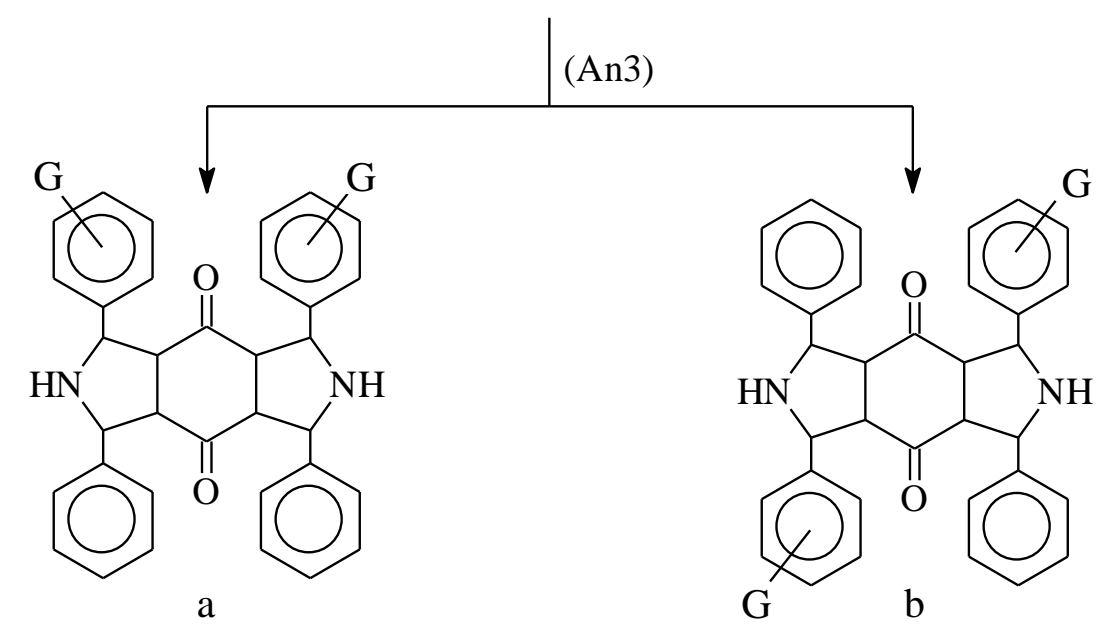

Scheme (2): 1,3-Anionic cycloaddition of Schiff bases to benzoquinone 
Table (3): Heat of formation (H.F) and steric energy (S.E) of final products (7-12)

\begin{tabular}{|c|c|c|c|}
\hline Comp. No. & $\mathrm{G}$ & $\begin{array}{c}\text { H.F } \\
\text { (Kcal/mole })\end{array}$ & $\begin{array}{c}\text { S.E } \\
\text { (Kcal/mole) }\end{array}$ \\
\hline 7 & $\mathrm{H}$ & 75.67686 & 32.041 \\
\hline $8 \mathrm{a}$ & $\mathrm{o}-\mathrm{Cl}$ & 67.84922 & 36.677 \\
\hline $8 \mathrm{~b}$ & $\mathrm{o}-\mathrm{Cl}$ & 69.36917 & 37.992 \\
\hline $9 \mathrm{a}$ & $\mathrm{p}-\mathrm{Br}$ & 85.13160 & 32.364 \\
\hline $9 \mathrm{~b}$ & $\mathrm{p}-\mathrm{Br}$ & 85.36518 & 32.868 \\
\hline $10 \mathrm{a}$ & $\mathrm{p}-\mathrm{NO}_{2}$ & 82.25546 & 60.478 \\
\hline $10 \mathrm{~b}$ & $\mathrm{p}-\mathrm{NO}_{2}$ & 83.03306 & 62.642 \\
\hline $11 \mathrm{a}$ & $\mathrm{p}-\mathrm{MeO}$ & -0.22045 & 56.436 \\
\hline $11 \mathrm{~b}$ & $\mathrm{p}-\mathrm{MeO}$ & -0.21508 & 56.537 \\
\hline $12 \mathrm{a}$ & $2,4-\mathrm{DiMeO}$ & -70.90630 & 79.403 \\
\hline $12 \mathrm{~b}$ & $2,4-\mathrm{DiMeO}$ & -69.79603 & 80.163 \\
\hline
\end{tabular}

One mole of An3 is added to one mole of benzoquinone may lead to the production of the intermediate $M$ through 1,3-anionic cycloaddition. The carbon-carbon double bond of $\mathrm{M}$ is still ready for another 1,3-anionic cycloaddition of another mole of An3 to afford either a or b. The heat of formation of $8 \mathrm{a}$ is $(67.84922) \mathrm{Kcal} / \mathrm{mole}$ and the steric energy is (36.677) $\mathrm{Kcal} / \mathrm{mole}$ while $8 \mathrm{~b}$ has a heat of formation of (69.36917) Kcal/mole and steric energy of (37.992) Kcal/mole. It may be concluded that according to the values of heat of formation (a) may be predominate among (b) (Table 3). On the light of spectroscopic evidences, the structures of final products (7-12) may established (Table 2).

The UV spectra showed a range of (294-346) $\mathrm{nm}$ for the wavelengths at maximum absorption which lies in the range of similar compounds ${ }^{(15)}$.

The FT-IR spectra showed a range of strong absorption bands for carbonyl group (1670-1600) $\mathrm{cm}^{-1}$ which fits the values for quinones ${ }^{(16)}$ or saturated diones ${ }^{(17)}$, while broad bands in the range of (3421-3062) $\mathrm{cm}^{-1}$ related to the stretching vibration ${ }^{(18)}$ of $\mathrm{N}-\mathrm{H}$. The pyrrolidine exhibits a weak basic properties which may lead to the protonation of N-H group to afford the cation $\mathrm{NH}_{2}{ }^{+}$that reflects an absorption ${ }^{(19)}$ band range of (23612360) $\mathrm{cm}^{-1}$. For compound number (10) a strong band seemed at (1527) $\mathrm{cm}^{-1}$ which is related to the symmetric stretching of nitrogen-oxygen bond of nitro group ( $\square \mathrm{N} \cdots \mathrm{O}$ ).

It is concluded from the values of the heat of formation of the final products (Table 3 ) that the type of the substituent on the aromatic ring of the Schiff base may play an important role in controlling the rate of the reaction. The electron withdrawing groups (deactivators) in the electrophilic aromatic substitution such as $\left(\mathrm{o}-\mathrm{Cl}, \mathrm{p}-\mathrm{Br}, \mathrm{p}-\mathrm{NO}_{2}\right)$ needs 
values of heat of formation in the range of $( \pm 10) \mathrm{Kcal} / \mathrm{mole}$ compared with the unsubstituted rings whereas electron-donating groups (activators) such as (p-OMe, 2,4-DiMeO) exhibits a negative values of (H.F), i.e: occurred spontaneously.

\section{Biological activity of pyrrolidines: \\ I. Preface:}

Some pyrrolidines possess biological activities such as anticancer ${ }^{(20)}$, antiaids ${ }^{(21)}$ and anti-inflammatory properties, while others, however, have analgesic $^{(22)}$ and anti pyretic values ${ }^{(23)}$.

In the present work, it is decided to choose some synthesized fused pyrrolidines to test their inhibition activity on the growth of two kinds of bacteria (Gram positive and Gram negative using the sensitivity test by disk diffusion method) ${ }^{(24)}$.

\section{Disk diffusion method:}

In nutrient broth a loopful of each type of bacteria species was cultured and incubated at (37) ${ }^{\circ} \mathrm{C}$ for (18-24) hours. The colloid is then diluted by normal saline and compared with the standard test tube Macferland No. 1, which prepared by the addition of (0.6) $\mathrm{ml}$ of barium chloride, the volume is completed to $(10) \mathrm{ml}$ by the addition of $0.1 \%$ sulfuric acid in a manner permit the solution to contain about $1 \times 10^{8}$ cell $/ \mathrm{ml}$ of the colloid, then evenly distributed on the nutrient agar by using a sterile swab.

The plates were incubated at $(37){ }^{\circ} \mathrm{C}$ for (30) minutes for the diffusion to be occurred. To study the biological activity of the pyrrolidines on the growth of bacteria, different concentrations of pyrrolidines were prepared $(100,50,25,12.5) \mathrm{mg} / \mathrm{ml}$. The filter paper (Whatmann No. 1) disc were distributed on the agar and a certain equal amounts $(1 \mathrm{mg} / 1 \mathrm{ml})$ or $(1 \mathrm{ml} / 1 \mathrm{ml})$ of the compound per solvent (DMSO) were $\operatorname{added}^{(25)}$.

The control here were standard antibiotics like Cephalothine and Chloramphenicol, the comparison depends on the diameter of the inhibition zone. The tested compound will be considered as sensitive (S) if the diameter of its inhibition zone is equal or larger than that of the standard antibiotic, and it is resistant (R) if its diameter of the inhibition zone is less than the antibiotic's zone. It was found that $S$. Aureus seemed sensitive to Cephalothine with inhibition zone of (17) mm, while E. coli was sensitive to Chloramphenicol and has a diameter of (22) $\mathrm{mm}$. The tested compounds, however, reflect a different effects. So it seemed that compounds (1-5) with different concentrations have no considerable effect on $E$. coli and it was resistant to these and the diameters of inhibition zones were $(7,8,8) \mathrm{mm}$ for $(5-7)$ respectively. While $S$. aureus was resistant to compounds (1-3) in different concentration, but for (4-7) at $100 \mathrm{mg} / \mathrm{ml}$, the inhibition zones were $(7,9,9,9)$ respectively. 


\section{REFERENCE}

1. T.J. Donhoe, C.E. Headley, R.P.C. Cousins and A. Cowley, organic Letters, Vol. 5, No. 7, pp. 999-1002, 2003.

2. J.M. Betancort and C.F. Barbas, organic Letters, Vol. 3, No. 23, pp. 3737-3740, 2001.

3. W.H. Pearson, Pure Appl. Chem., Vol. 74, No. 8, pp. 1339-1347, 2002 .

4. T. Kauffmann, Angew. Chem., Int. Ed. Engl., 13, pp. 627-639, 1974.

5. D. Enders, C. Thiebes, Pure Apple. Chem., 73, 573, 2001.

6. Seyden-Penne, J. Chiral Auxilliaries and Ligands in Asymmetric Synthesis, John Wiley: New York, 1995.

7. R.L. Shriner, R.E. Fuson, D.Y. Curtin, "The Synthetic Identification of Organic Compounds", $5^{\text {th }}$ Ed., John Wiley and Sons Inc., New York, p. 29, 1964.

8. A. Vogel, "Practical Organic Chemistry", Longmans, $2^{\text {nd }}$ Ed., p. $625,1951$.

9. D.E. Williams and I. Fleming, "Spectroscopic Methods in Organic Chemistry", $2^{\text {nd }}$ Ed., McGeaw-Hill, England, p. 18, 1973.

10.A.R. Katritzky and C.W. Ress, "Comprehensive Heterocyclic Chemistry", $1^{\text {st }}$ Ed., Pergamon Press, New York, Vol. 5, p. 278, 1984.

11.K. Popandova-Yambolieva and C. Ivanov, Chemica. Scripta., Vol. 29, pp. 269-271, 1989.

12.Reference 9, p. 29.

13.Reference 9, p. 60.

14.A.Al-Hamdany ,Ph.D.Thesis , Mosul University ,pp.152-154,2002.

15.Reference 9, p. 18.

16. Reference 9, p. 57. 
17.V.M. Parikh, "Absorption Spectroscopy of Organic Molecules", Addison-Wesley Publishing Company Inc., pp. 247-252, 1974.

18. Reference 17, p. 531.

19. Reference 9, p. 51.

20.V. Vicker, J. Med. Chem., vol. 45, p. 721, 2002.

21.L. Liotta, "Louis Liotta's Research Interest", Am. Chem. Soc. Inc., p. 1, 2003.

22.E. Lilly, J. Med. Chem., Vol. 34, pp. 397-403, 1991.

23.Glaxo, J. Med. Chem., Vol. 39, pp. 4478-4482, 1996.

24.A.W. Bauer, W.A. Kirby, J. Sherris and M. Turk, "Antibiotic Susceptibility Testing by Standardized to Single Disc Method", Am. J. Clin. Pathol., Vol. 45, pp. 493-496, 1966.

25.D.J. Merius, K.T. Veldman, R.H.M. Vaerpal and F.G. Zijderveld, "Sensitivity Testing of Veterinary Pathogens with a Semiautomatiz Image Analysis System Compared with Tablet Diffusion and Agar Dilution Tests", Vol. 21, No. 3, pp. 99-104, 1999. 